Vol. 6, No. 2, 2019

https://doi.org/10.23939/eem2019.02.047

UDC 657.1

JEL Clasification Code M5, M21

\author{
S. Lehenchuk \\ Zhytomyr State Polytechnic University, Ukraine, Doctor, Professor, \\ E-mail: legenchyk2014@gmail.com \\ ORCID: 0000-0002-3975-1210
}

\title{
HISTORICAL ASPECTS OF THE DEVELOPMENT OF ACCOUNTING SYSTEM IN THE CONTEXT OF HOSTILITIES
}

\begin{abstract}
The urgency of carrying out scientific researches on the influence of military actions on the accounting system is substantiated in the article. The main directions of the development of accounting system in the context of the military operations implementation (accounting system for the subjects of the military operations, accounting system for enterprises that provides a support in the course of military conflicts, accounting system for the property of enterprises, whose activities were directly influenced by military actions, is considered as a political tool for military conflicts). It is substantiated that the occurrence of hostilities leads to the transformation of the accounting system - its simplification, both in the subjects of their implementation, and in enterprises that provide support during military conflicts. Control function is the most important function of accounting system during the war, the implementation of which allows to mobilize the resources necessary to effectively counteract the aggressor country. It has been established that in the condition of hybrid war, domestic enterprises adjust the value of assets over which control has been lost. A promising area of the research is the consideration of accounting system as a political tool in military conflicts.
\end{abstract}

Key words: accounting system, history of accounting system, hostilities in Ukraine, hybrid war, accounting system as a socio-economic institute.

\section{Introduction.}

The development of accounting system as a separate functional science and as a practical activity directly depends on the actions and events occurring in its environment. On the one hand, environmental factors are considered as the objects of accounting system (for example, changes in the exchange rate or value of the securities in the capital market), and, on the other hand, causes the need for the transformation of theoretical and methodological principles of the accounting system. One of these factors is the implementation of hostilities that affects most of the processes occurring in society, in particular, this causes a violation of traditional approaches to business activities, which significantly affects both the objects of accounting system and the order of accounting system organization at the enterprises.

\section{Literature review.}

Problems of the accounting system development in the context of military operations are devoted to the work of A. Belousov and A. Zelenyna (Belousov and Zelenyna, 2010), S. Vedernykov and E. Rosenberh (Vedernykov and Rosenberh, 1947), J. Wollmers, V. Antonelli, R. D'Alesio and R. Rossi (Vollmers et al., 2016), A. Djed and R. Sarikas (Djedj \& Sarikas, 2009), A. Kashaev and A. Shein (Kashaev and Shein, 1985), V. Mazdorov (Mazdorov, 1972), V. Funnell and M. Chvwastiak (Funnell \& Chwastiak, 2015). However, these studies mainly reveal the problems of the accounting system functions transformation and the development of accounting system practices during the classical form of conducting hostilities that took place during the twentieth century, without taking into account other contemporary forms that affect the functioning of national accounting system. The expansion of the military-political conflict in the East of Ukraine, which began in 2014 and still continues, as well as the conduction of the hybrid war by the Russian 


\section{S. Lehenchuk}

Federation, necessitate an analysis of the directions of accounting's development during the hostilities based on the study of existing historical experience and the rethinking of the value of accounting system as a means of ensuring the level of national security.

The main purpose of the research is to isolate and analyze the areas of accounting system development in the context of military operations. The achievement of this goal will allow to systematize all possible variants of the accounting system's development in the context of the implementation of military operations, which will formulate the ways of their practical implementation, and link the role of accounting system as a political tool in military conflicts.

\section{Methodological approach.}

The methodological basis of the study is the historical method and system approach, which allowed to consider in the historical retrospective of the peculiarities of the development of accounting system during hostilities, to identify the historical patterns of such development, and to formulate general directions of the development of the national accounting system in this context. To substantiate the understanding of the essence of accounting system as a political tool during military conflicts, the socio-positive theory was used. According to the theory, the accounting system is considered not as a passive observer and registrar of the consequences of economic life's facts, but as an active participant in socio-economic processes related to the activity of the enterprise. The results of statistical observations based on financial statements, audit findings and litigation were used to determine the procedure for the assessment of the lost property of domestic enterprises as a result of hybrid military aggression.

\section{Conducting research and results.}

The analysis of the professional literature on the accounting system shows that the issue of the development of accounting system in the context of military operations in the post-Soviet countries is traditionally associated with the Second World War. At the same time, this topic is widely covered in the world literature on accounting system both as an example of specific wars, and through the search for common features regarding the transformation of the accounting system in military conflicts. In recent years, such studies have become relevant in the Russian Federation's hybrid war against Ukraine.

If we consider war as a separate factor in the external environment of the national accounting system, then we can state that in such difficult periods for a country, scientists do not pay due attention to the development of accounting system, so it usually remains the same without progressive changes, or on the contrary, is partially degraded by its gradual simplification in order to fulfill the tasks brought to it by users and dictated by the terms of wartime.

As a result of the analysis of scientific publications, one can distinguish the following areas of development of accounting system in the conduction of hostilities (Figure 1).

\begin{tabular}{c}
$\begin{array}{c}\text { Areas of the development of accounting system } \\
\text { in the context of the conduct of hostilities }\end{array}$ \\
$\qquad \rightarrow$\begin{tabular}{l|} 
Accounting system for actors in the conduct of hostilities \\
Accounting system at enterprises that perform a providing function during \\
military conflicts
\end{tabular} \\
\hline $\begin{array}{l}\text { Accounting system for the property of enterprises whose activities were directly } \\
\text { influenced by military actions (lost or conquered) }\end{array}$ \\
\hline Accounting system as a political tool in the conduct of military conflicts \\
\hline
\end{tabular}

Fig. 1. Areas of the accounting system's development in the context of hostilities 


\section{Historical aspects of the development of accounting system in the context of hostilities}

I. Accounting system for the actors in hostilities (military units). During the war, the accounting system and financial apparatus of military units, as state structures, operates under extremely hard conditions, which in many cases do not allow the full implementation of the main accounting system functions, and leads to the need for simplification of accounting system and its adjustment under the existing conditions. Changing the form of accounting system in the direction of its simplification is usually dictated by an attempt to ensure the efficiency and reliability of accounting system information, which significantly damages its relevance.

The need to change the existing accounting system rules during hostilities was foreseen even in the records of the registration of military units published during peacetime. Thus, in the "Regulations on the management of the economy in separate parts of the troops", 1904 (Zashehuk, 2003), it is noted that there is a possibility of derogations from the traditional practice of reporting during the war time. In particular, it was allowed: 1) to prolong the reporting time of the received treasury funds; 2) the head of the economy could himself implement the accounting system policy without the consent of the regiment commander, but the cost should have been not more than thousand rubles; 3 ) the ability to increase the amount of advances issued at the discretion of the regimental commander. Thus, the differences in keeping records in peace and war time were the possibility of slightly transforming existing accounting system practices in connection with the occurrence of complications in communication between the subject of accounting system (the manager of the economy) and the person responsible for his organization (commander of the regiment).

During the hostilities, more radical changes are made in the accounting system. In particular, according to S. Vedernykov and E.. Rosenberhyh, explaining the peculiarities of the organization of accounting system during the Second World War, the specific conditions of financial activity of the military units in the current army require some changes in the practice of financial accounting system and reporting of troops. The practice during the first months of the war showed that the peaceful forms of financial accounting system in military units were excessively detailed and technically not adapted to the conditions of wartime. In order to simplify and unify financial accounting, the main accounting system registers for the financial sector of the military unit used in peacetime were subject to restructuring in relation to the prevailing conditions (Vedernykov and Rosenberh, 1947). One of such important and fundamental decisions was the introduction of a special register - a checklist that was supposed to overcome the problem of the absence of military units of their current accounts and the need to release their money and government bond bonds. Another example of the simplification of accounting system procedures was the introduction in August 1941 of a simple standard form of a monetary book, which replaced the money magazine and the book of monetary personal accounts. In addition to the convenience of this book, its format was also adapted to a field bag used by counters of military units for its storage, which in general improved the reporting process by military units in the context of hostilities.

One of the consequences of the war is the increase in the proportion of women in accounting services and in general at enterprises, which was especially noticeable at a time when all men able for war were recruited into the army, and the process of its implementation required spending significant amounts of human resources. In particular, when Black, (2006), had investigated the role of women in the British Military Payroll Department during the First World War, and analyzed the peculiarities of the historical development of the accounting system profession, he confirmed that widespread involvement of women in the implementation of accounting system procedures was an example of proto- feminization of British accountancy. In general, this fact can be considered as the main reason for the growth of the number of women accountants in the postwar years in the USSR, where this figure in 1985 reached $89 \%$ (National Economy of the USSR for 70 years, 1987).

II. The accounting system of enterprises that perform a provisioning function during military conflicts is also an object of change, which is dictated by the need to transform the enterprise management system under war conditions. The depth of such changes depends on the peculiarities of the military conflict, in particular, on the level of 


\section{S. Lehenchuk}

its impact on the country's economy. If this is a local conflict that does not significantly change the functioning of the national economy, the national accounting system will also not undergo significant changes. At the same time, there may be some changes in the existing accounting methods related to the activities of enterprises that ensure the functioning of the army. So, J. Wollmers, V. Antonelli, R. Dalescio and R. Rossi (Vollmers et al., 2016) cite examples of the changes in the methodology of managerial cost accounting in Italian industrial groups that seek to obtain price advantages for further participation in tenders and auctions conducted by the Ministry of Defense and the Ministry of Ammunition of Italy during the First World War. Another example of such changes that affect the methodology of accounting system for enterprises preparing for hostilities is the publication of the US Accounting Committee for Accounting Procedures ARB 13 "Accounting for Special Reserves Arising After the War", 1942 (Accounting for Special Reserves Arising Out of The War, 1942).. This document discloses the features of accounting reflection and the subsequent use of reserves that have already been created and can be created by enterprises engaged in the production for military purposes or significantly suffering as a result of hostilities.

If the military conflict changes the basic principles of the functioning of the national economy, gaining for a specific country of an inclusive scale (for example, gaining the status of domestic war) and forcing to switch to a model of management of enterprises taking into account the needs of "military time", then under such conditions there is a change in the requirements for the functioning of the national accounting systems both at the level of the system of regulation, and at the level of organization and methodology of the operation of a specific enterprise accounting system. The most typical example is the Soviet accounting system, which has undergone significant changes during 1941-1943. According to V. Mazdorov, the military situation in the country identified new tasks for accounting. The war has become the reason for the restructuring of accounting system, which was reflected in its simplification and reduction of reporting, increased operational control over economic expediency, the preservation of socialist property, and the economical spending of funds and materials (Mazdorov, 1972). A similar thesis became common for the representatives of the Soviet accounting system. Ya. Halperyn, N. Kyparysov and N. Leontiev also notes that the fascist Germany's attack on the Soviet Union has given rise to increasing attention to the correct recording and reporting of socialist enterprises. During the war, a lot of work was done to streamline accounting and reporting, to reduce and simplify the forms of reporting (Halperyn, Kyparysov and Leontev, 1945). A. Kashaev and A. Shein also emphasizes that during the war there were significant changes in the organization of accounting; it was necessary to implement a very strict regime of economy and control over the costs of material, labor and financial resources with a particular persistence (Kashaev and Shein, 1985).

Thus, the most important function of accounting system during the war was a control function, the fulfillment of which created the prerequisites for effective counteraction to the aggressor country, in particular, through increasing the efficiency of the use of available resources and finding the deep reserves of the national economy. As history showed, such a reorientation of accounting system gave positive results. A. Djaatej and R. Sarikas emphasized that accounting system itself played an important role in the process of obtaining a victory in the war by the Soviet Union (Djaatej \& Sarikas, 2009).

In addition to simplifying the accounting system procedures that took place in the production cost formation, capital expenditures, as well as simplifying the reporting procedure (monthly telegraph reporting), the methodology of Soviet accounting system has changed considerably. As a result of violations of economic relations between enterprises there were significant amounts of overdue debts, and a significant amount of losses and unforeseen costs, for which account was introduced special accounts, in the name of which was the reason for their isolation - the terms of military time. The simplification of the accounting system, in particular, the abandonment of a large number of primary documents, made it possible to introduce new economic instruments, one of which was the card system of the distribution of food, introduced in the USSR in July 1941, and provided 


\section{Historical aspects of the development of accounting system in the context of hostilities}

the establishment of rates of consumption of goods per person per month.

During the war there was also a transformation of the approaches to accounting system organization, which was conditioned by a chronic shortage of trained accountants and a reduction of time for the implementation of the accounting process. According to A. Belousov and A. Zelenyna, during the war began to widely use group (cumulative) information on cash and banking operations, as well as procurement of material values and settlements with suppliers, shipments of inventory and payments to buyers. The harmonization of chronological and systematic registers, simplification of the distribution of maintenance and management costs, the use of the coefficient method in determining the cost price of certain types of products, etc. was recommended (Belousov and Zelenyna, 2010). In general, the authors came to the conclusion that the results obtained during the war in organization of the future accounting system were the basis for the development of journal-order form of accounting, which in the early 1950's began to be widely implemented in various sectors of the national economy of the USSR.

In such a case, when a civil war takes place in the country, which is a form of the solution of contradictions that arise between different sections of the population, and which ends with the victory of the party that is embarking on reforming the economic structure adopted in the country, the accounting system also undergoes significant changes. The extent of such changes depends on the contradiction level between the previous economic pattern and the newly created post-civilian outcomes. Thus, as a result of the civil war in the United States (1861-1865), slavery was abolished (1865) and that led to the need to exclude from the accounting system the accounts used to record the slaves and value them.

The consequence of the civil war in Russia (1917-1923) was the coming to power of the Bolshevik Party and the gradual establishment of a Soviet government on the overwhelming majority of its territory, which over the next ten years formed the model of Soviet accounting, which fundamentally differed from market-based accounting system at the theoretical, methodological, and organizational level. The definitive methodological feature of Soviet accounting system was the transition to a monotonous accounting regulation, which in general led to the formation of the concept of expanded univariance of accounting methodology (Legenchuk, 2017). Thus, the accounting system of enterprises that perform a provisioning function during armed conflicts may undergo changes depending on the peculiarities of the military conflict that determine its role in the economic life of a particular country.

III. The property accounting of enterprises, whose activities were directly influenced by military actions (conquered or lost). The hostilities between the armed forces of certain countries or political entities in most cases has economic preconditions, which is justified by the limited resources and unlimited needs of people. In some cases, the desire of participants in the war to seize the necessary resources or entire economic areas determined the nature of combat operations and the direction of the deployment of military aggression. The reason for the war may be claims for property rights or territory which belongs to the other party to the armed conflict. As a result of the success of such claims of one party to the conflict as a result of nationalization (expropriation) there is property that needs to be reflected in accounting, and the other party - there is a disposal of such property that can be considered from the standpoint of accounting as a loss or as a temporary loss.

The most typical example of expropriation of property in the captured territories is the actions of Germany during the Second World War. Thus, during the years of occupation, German troops looted and destroyed $38 \%$ of Polish national property, 63 million tons of coal and about 2 million tons of oil were extracted from France, and all stocks of strategic raw materials were exported from Belgium, Holland, Denmark, Norway and other occupied countries, industrial goods and food, 80 million dollars of gold were exported from Austria, and 25 million dollars from Czechoslovakia (Shifman, 1964). The expropriated property was exported from the occupied countries to Germany, which was included in the assets of powerful German monopolies or public financial institutions.

A similar situation at the end of the Second World War was in the former Soviet territories, which were liberated from the German occupation 


\section{S. Lehenchuk}

by the Soviet troops, as well as in the territories that were liberated but were not included into the USSR. However, the nationalization of property was already carried out by representatives of Soviet power. In order to ensure proper control and unification of this process in April 1943, the Council of People's Commissars of the USSR issued Decree No. 404 regulating the issues of accounting and the use of nationalized, confiscated, depreciable and landless property. In particular, according to Art. 4 of this document, all issues related to the identification, accounting, valuation and sale of property, valuables and funds must be carried out by the financial authorities (Approval of the provision on the procedure for the accounting and use of nationalized, confiscated, escheat and ownerless property, 1943). The transfer of nationalized and confiscated property was carried out by the financial authorities by the cooperation with higher authorities both on a royalty-free basis and on a fee basis, using actual value, purchase prices, etc.

When establishing of the new government in the territory entrenched in the war as a result of the accession of such a territory to another country or the creation of a new country by combining several territories, the enterprises and institutions existing on it are usually the subject to nationalization. Thus, in 1917, on the territory of post-revolutionary Russia, all the banks and the banking state monopoly, railway transport, the navy and the annual fleet were nationalized, and in June 1918 a separate decree proclaimed the nationalization of the whole large industry (enterprises with more than 1 mln. Rubles of assets). According to A. Lozynskyi after the nationalization of 1917-1918, the highest leadership was involved in organizing the correct accounting system of the means of production expropriated in the bourgeoisie and ensuring the preservation of the state fund (Lozynskyi, 1939). Thus, one of the consequences of hostilities is the seizure of property and new territories, with enterprises placed on them. As a result of nationalization, these objects should be included in the assets of enterprises and institutions. The main problem of their accounting system is the establishment of their real worth, taking into account their real value, and the costs incurred for their delivery and transfer to their place of their subsequent use. In the other party to a military conflict which loses it on a temporary or permanent basis, there is a loss of certain types of property, enterprises or territories, which should also be reflected in the accounting system of the corresponding level.

In order to account the lost property during the Second World War, a separate (27th) section of the invoice plan was introduced at Soviet enterprises D "The wartime accounts". According to V. Mazdorov, this section included 21 first-order invoices and two sub-accounts, for example: 270 - "Fixed assets are not evacuated"; 251 - "Materials on the way that did not arrive before evacuation to the enterprise"; 252 - "Inventories are not evacuated"; 253 "Commodity-material values evacuated, but not arrived at the location of the enterprise", etc. (Mazdorov, 1972). The introduction of such proposals was based on the general policy of the need to evacuate the most important enterprises from the front-line districts to the eastern part of the Soviet Union, which was practically implemented through the evacuation council set up in 1941. Accordingly, the proposed system of accounts was intended for the accounting of those assets of the enterprise that were either not evacuated (by type of assets) or did not reach a definite place for their evacuation, as well as for accounting receivables and creditor indebtedness, as there were significant doubts to their repayment due to the capturing of the territory where the enterprises were located and even after the evacuation, such enterprises have not yet restored their activity. All other evacuated objects were counted using other traditional accounts used by enterprises in the peaceful period of time.

During the evacuation of property, the primary responsibility for the safety of evacuation and the subsequent formulation of such property was taken by the accountants who were required to strictly adhere to the existing requirements, in particular, regarding the documentary registration of such transactions. At the same time, in the process of evacuation of the property of enterprises, significant expenses were incurred, which had to be reflected in the corresponding accounts ("Expenses caused by evacuation"), and in many cases the property did not reach its final destination as a result of the rapid advance of the enemy troops, and as a result inefficient logistics. Therefore, one of the 


\section{Historical aspects of the development of accounting system in the context of hostilities}

directions of the development of the accounting system during the war was the improvement of the accounting record of non-documentary cargoes.

Today, under the conditions of temporary occupation of certain territories in the Donetsk and Lugansk regions and the annexation of the Crimea, at domestic enterprises whose structural units remained in these territories and over which the management was stopped, such a method of accounting system for lost property used during World War II in the Soviet accounting system in not used. For example, all nationalized property of DTEK ENERGY BV, located in the occupied region of Donetsk and Lugansk and in the annexed Crimea, is included in the assets of this company, as evidenced by the published unaudited consolidated financial results for the six months of 2018 (Results Corporate Presentation DTEK ENERGY BV, 2018). However, according to the Audit Opinion on DTEK CRIMENERGO's Financial Statements dated March 20, 2017 (Auditor's Report on the Financial Statements of PJSC DTEK CRIMENERGO, 2017), the value of non-current assets located in the temporarily occupied territory of Ukraine, in 2015 a $100 \%$ impairment provision was accrued based on prudence and IFRS 36, "Impairment of Assets." As a result, in 31.12.2016, net assets of PJSC "DTEK CRIMENERGO" were negative - -1025951 thousand UAH. In September 2018, the media reported that DTEK ENERGY BV was being sued at international courts in the Russian Federation for expropriated property located on the territory of the annexed Crimea (DTEK was sued in international courts in Russia for the stolen property during the annexation of the Crimea, 2018), which testifies to the enterprise's efforts to compensate for the losses incurred. Accordingly, for the assets of DTEK ENERGY B. V., which remained in the occupied part of the Donetsk and Luhansk Oblasts and in the annexed Crimea, separate special accounts for their accounting system are not used, and their value is adjusted on the basis of their level of depreciation.

Additionally, in accordance with IFRS 36, "Impairment of Assets", asset utilization decreases not only as a result of the loss of control over such assets, but also when specific assets lose their value because of the breach of contract performance or in case of termination. Today's situation is typical for the assets of the thermal power plants included in
DTEK ENERGY B.V., since after the loss of control over the mines that were the main suppliers of anthracite, their value needs to be re-evaluated as a result of the losses. In more detail, this issue is covered in the study. Iukhymenko-Nazaruk (Iukhymenko-Nazaruk, 2017), which implies the use of the provisions of the non-institutional theory, requires the use of the concept of specific assets in accounting, which will justify the ways to improve the accounting in a hybrid war.

IV. Accounting system as a political tool in military conflicts. According to the traditional point of view, the accounting system is considered as a means of fixing the results of hostilities and as a means of providing information management to enterprises that support the subjects of war. In this approach, accounting system performs a passive function during military conflicts. Unlike this approach, inspired by the representatives of the London School of Economics (E. Hopwood, P. Miller, A. Bemanni, M. Bromovich, etc.), V. Funnell and M. Chwastiak proposed to consider accounting system as a political tool that can be used by the entities of its organization to overcome political crises. That means that the accounting system is proposed to be considered not as something derivative and secondary, necessary to reflect the existing economic reality, but as a primary thing in relation to social processes and relations that are formed as a result of the functioning of accounting system as a separate socio-economic institute.

According to the authors, for all national states the account of military operations served to realize wider political goals. From the Crimean War to the war on terrorism, accounting system was used to establish civilian control over the military, the introduction of sound business practices in the war, and the creation of visible and invisible reasons that should legitimize the use of force (Funnell \& Chwastiak, 2015). Through the implementation of the information function, accounting system allows political elites to justify the reasons for a military conflict, and due to the control - to influence the subjects of the implementation of military conflicts, thus, simultaneously influencing the order of deployment of military action. 


\section{S. Lehenchuk}

\section{Conclusion}

One of the environmental factors that affect the development of the national accounting system is military actions that affect both their parties and other actors whose activities are influenced by the hostilities. On the basis of the analysis of scientific publications, four main directions of the development of accounting system during military operations are identified: 1) Accounting for the subjects of the conduct of hostilities; 2) Accounting system at enterprises that perform a providing function during military conflicts; 3) The property accounting of enterprises, whose activities were directly influenced by military actions; 4) Accounting system as a political tool during military conflicts).

During military operations, there is a transformation of existing approaches to the organization of accounting system - its simplification, as well as the adaptation of the methodology of accounting of assets and liabilities as a result of changing the normal conditions of the operation of enterprises. During hybrid war, it is necessary to improve the methodology of the valuation of assets over which control has been lost, and the methodology for evaluating specific assets, the execution of contracts whose operation was endangered by the opportunistic behavior of counteragents or changes in the regulatory regulation of enterprises. A promising direction for conducting the further research is to deepen the public value of accounting system as a social and institutional practice, in particular, to reveal its role as a political tool or social ideology that can be used to overcome socio-political crises associated with military conflicts.

\section{References}

1. Audytorskyi vysnovok (ZVIT NEZALEZhNOHO AUDYTORA) vid 20 bereznia 2017 r. shchodo finansovoi zvitnosti PAT «DTEK KRYMENERHO» [Auditor's Report (INDEPENDENT AUDITOR'S REPORT) dated March 20, 2017, on the financial statements of PJSC "DTEK CRIMENERGO"]. Retrieved from https://dtek.com/content/files/ auditorskiy-visnovok-schodo-finansovoi-zvitnostitovaristva-za--2016-rik.pdf [in Ukrainian].

2. Belousov, A. Y. \& Zelenina, A. V. (2010). Osobennosti buhgalterskogo ucheta $v$ period velikoy otechestvennoy voyny [The features of accounting system during Great patriotic War].
Vestnyk Stavropolskogo gosudarstvennogo universiteta - Messenger of Stavropol State University, 68, 13-17 [in Russian].

3. Vedernikov, S.S. \& Rozenberg, E.K. (1947). Kurs buhgalterskogo ucheta dlia podgotovki schetovodov [The course of accounting systemfor the preparation of accountants]. Leningrad: "Typography named after Volodarsky» [in Russian].

4. Halperin, Ya.M. \& Kyparisov, N.A. \& Leontev, N.A. (1945). Kurs teorii buhgalterskogo ucheta [The course of accounting theory]. Moscow: «GOSPLANIZDAT» [in Russian].

5. DTEK pozyvaietsia v mizhnarodni sudy do Rosii za vkradene pid chas aneksii Krymu maino [DTEK is sued in international courts in Russia for property stolen during the annexation of Crimea] Retrieved from http://www.umoloda.kiev.ua/number/0/2006/ 126257/ [in Ukrainian].

6. Zashchuk, Y. (1904). Polozhenie ob upravlenii hozyaystvom $v$ otdelnyh chastyah voisk. [Regulations on the management of the economy in certain parts of the troops]. Varshava: "Typography of the district headquarters» [in Russian].

7. Kashaev, A. N. \& Shein, A. V. (1985). Ob organizacii buhgalterskogo ucheta $v$ period Velykoy Otechestvennoy voiny [On the organization of accounting during the Great Patriotic War] // Bukhhalterskyi uchet - Accounting. 5. 16-18 [in Russian].

8. Lehenchuk, S. F. (2017). Bahatovariantnist v bukhhalterskomu obliku: istoryko-teoretychni aspekty [Multivariance in accounting: historical and theoretical aspects]. Zhytomyr: ZhDTU [in Ukrainian].

9. Lozinskiy, A. Y. (1939). $K$ istorii razvitiya buhgalterskogo (balansovogo) ucheta. Opyt (skhema) issledovaniya [To the history of the development of balance accounting]. Saratov: «Kommunist» [in Russian].

10. Mazdorov, V. A. (1972). Istoriya razvitiya buhgalterskogo ucheta $v$ SSSR: 1917-1972 gg [The history of the development of accounting in the USSR: 1917-1972]. Moscow: «Finance» [in Russian].

11. Narodnoe hozyaistvo SSSR za 70 let (1987) [The national economy of the USSR for 70 years]. Moscow: «Finance and statistics» [in Russian].

12. Postanovlenie Soveta Narodnyh Komissarov SSSR № 404 "Ob utverzhdenii polozheniya o poryadke ucheta $i$ ispolzovaniya natsionalizirovannogo, konfiskovannogo, vymorochnogo $i$ beshozyainogo imuschestva" (1943) [Resolution of the Council of People's Commissars of the USSR No. 404 "On Approval of the Provision on the Procedure for 
Historical aspects of the development of accounting system in the context of hostilities

Accounting and Use of Nationalized, Confiscated, Fatal, and Ownerless Property"]. Retrieved from http://docs.cntd.ru/document/901855443 [in Russian].

13. Shifman, M. S. (1964). Voyna i ekonomika (vooruzhennoe vozdeistvie na ekonomiku voyuyuschih stran $v$ pervoy $i$ vtoroy mirovyh voynah) [War and economy (armed influence on the economy of the warring countries in the first and second world wars)]. Moscow: «Voenyzdat» [in Russian].

14. Yukhymenko-Nazaruk, I. A. (2017). Rozvytok teorii $i$ metodolohii bukhhalterskoho obliku v konteksti neoinstytutsiinoi teorii [The development of the theory and methodology of the accounting region in the context of neoinstitutional theory]. Zhytomyr: Vydavets O.O. Yevenok [in Ukrainian].

15. $1 H 2018$ Results Corporate Presentation DTEK ENERGY B. V. Retrieved from https://dtek.com/ content/files/dtek_prez_irfy_new_2018-

autumn_main_final.pdf

16. Accounting Research Bulletins. Committee on Accounting Procedure. (1942). "Accounting for Special Reserves Arising Out of the War”, 13, 111-118.

17. Black, J. (2006). War, Women and Accounting: Female Staff in the UK Army Pay Department Offices, 1914-1920. Accounting, Business \& Financial History, 16, 2, 195-218.

18. Djatej, A. \& Sarikas, R. (2009). The Second World War and Soviet accounting. Accounting history, 14, 1-2, 35-54.

19. Funnell, W. \& Chwastiak, M. (2015). Accounting War: The Politics of Military Finance. "Routledge".

20. Vollmers, G., Antonelli, V., D’Alessio R. \& Rossi, R. (2016). Cost Accounting for War: Contracting Procedures and Cost-Plus Pricing in WWI Industrial Mobilization in Italy. Retrieved from http://ssrn.com/abstract $=2634591$ 